University of Nebraska - Lincoln

DigitalCommons@University of Nebraska - Lincoln

\title{
Eliminating Summer Fallow Reduces Winter Wheat Yields, but Not Necessarily System Profitability
}

Drew J. Lyon

University of Nebraska-Lincoln, drew.lyon@wsu.edu

David D. Baltensperger

University of Nebraska-Lincoln, dbaltensperger@tamu.edu

Jurg M. Blumenthal

Texas A\&M University, College Station

Paul Burgener

University of Nebraska-Lincoln, pburgener2@unl.edu

Robert M. Harveson

University of Nebraska-Lincoln, rharveson2@unl.edu

Follow this and additional works at: https://digitalcommons.unl.edu/panhandleresext

Part of the Agriculture Commons

Lyon, Drew J.; Baltensperger, David D.; Blumenthal, Jurg M.; Burgener, Paul; and Harveson, Robert M., "Eliminating Summer Fallow Reduces Winter Wheat Yields, but Not Necessarily System Profitability" (2004). Panhandle Research and Extension Center. 4.

https://digitalcommons.unl.edu/panhandleresext/4

This Article is brought to you for free and open access by the Agricultural Research Division of IANR at DigitalCommons@University of Nebraska - Lincoln. It has been accepted for inclusion in Panhandle Research and Extension Center by an authorized administrator of DigitalCommons@University of Nebraska - Lincoln. 


\title{
Eliminating Summer Fallow Reduces Winter Wheat Yields, but Not Necessarily System Profitability
}

\author{
Drew J. Lyon,* David D. Baltensperger, Jürg M. Blumenthal, Paul A. Burgener, and Robert M. Harveson
}

\begin{abstract}
Summer fallow is commonly used to stabilize winter wheat (Triticum aestivum L.) production in the Central Great Plains, but summer fallow results in soil degradation, limits farm productivity and profitability, and stores soil water inefficiently. The objectives of this study were to quantify the production and economic consequences of replacing summer fallow with spring-planted crops on the subsequent winter wheat crop. A summer fallow treatment and five spring crop treatments [spring canola (Brassica napus L.), oat (Avena sativa L.) $^{+}$ pea (Pisum sativum $\mathrm{L}$.) for forage, proso millet (Panicum miliaceum L.), dry bean (Phaseolus vulgaris L.), and corn (Zea mays L.)] were no-till seeded into sunflower (Helianthus annuus L.) residue in a randomized complete block design with five replications during 1999, 2000, and 2001. Winter wheat was planted in the fall following the spring crops. Five $N$ fertilizer treatments $(0,22,45,67$, and $90 \mathrm{~kg} \mathrm{~N}$ $\mathrm{ha}^{-1}$ ) were randomly assigned to each previous spring crop treatment in a split-plot treatment arrangement. The 3-yr mean wheat grain yield after summer fallow was $29 \%$ greater than following oat + pea for forage and $86 \%$ greater than following corn. The 3-yr mean annualized net return for the spring crop and subsequent winter wheat crop was $\$ 4.20,-\$ 6.91,-\$ 7.55,-\$ 29.66,-\$ 81.17$, and $-\$ 94.88 \mathrm{ha}^{-1}$ for oat + pea for forage, proso millet, summer fallow, dry bean, corn, and spring canola, respectively. Systems involving oat + pea for forage and proso millet are economically competitive with systems using summer fallow.
\end{abstract}

$\mathrm{W}$ ATER IS THE MOST limiting resource for dryland crop growth in the semiarid areas of the U.S. Great Plains (Smika, 1970). Summer fallow, the practice of controlling all plant growth during the non-crop season, is commonly used to stabilize winter wheat production in this region of high environmental variability. Wheat-fallow is the predominate cropping system in the Great Plains, but water storage efficiency during fallow is frequently less than $25 \%$ with conventional tillage (McGee et al., 1997). The advent of reduced- and notill systems have enhanced the ability to capture and retain precipitation in the soil during non-crop periods of the cropping cycle, making it possible to reduce the frequency of fallow and intensify cropping systems relative to wheat-fallow (Peterson et al., 1996).

In the Great Plains, annual precipitation is concentrated during the warm season (April-September). Hence, inclusion of a summer crop, e.g., corn or grain sorghum [Sorghum bicolor (L.) Moench], in a 3-yr sys-

D.J. Lyon, D.D. Baltensperger, P.A. Burgener, and R.M. Harveson, Panhandle Research and Extension Center, 4502 Avenue I, Scottsbluff, NE 69361; J.M. Blumenthal, 351C Heep Center, 2474 Texas A\&M University, College Station, TX 77843-2474. Journal Series No. 14154 of the University of Nebraska Agricultural Research Division. Received 30 June 2003. *Corresponding author (dlyon1@unl.edu).

Published in Crop Sci. 44:855-860 (2004).

(c) Crop Science Society of America

677 S. Segoe Rd., Madison, WI 53711 USA tem of wheat-summer crop-fallow, increased the efficient use of precipitation by reducing the frequency of summer fallow, which uses more water for crop transpiration (Farahani et al., 1998). In addition to increased precipitation use efficiency and grain yield, more intensified dryland cropping systems increase potentially active surface soil organic C and N (Peterson et al., 1998), effectively control winter annual grass weeds in winter wheat (Daugovish et al., 1999), and increase net return and reduce financial risk (Dhuyvetter et al., 1996).

Even in these more intensive cropping systems, summer fallow is typically used in the transition from a summer crop to winter wheat. In recent years, some western Nebraska growers have become interested in the idea of eliminating the practice of summer fallow. The objectives of this study were to quantify the production and economic consequences of replacing summer fallow after a full season summer crop with several spring-planted crops on the subsequent winter wheat crop.

\section{MATERIALS AND METHODS}

Field studies were established near Sidney, NE (Latitude $41^{\circ} 12^{\prime} \mathrm{N}$ Longitude $103^{\circ} 0^{\prime} \mathrm{W}$ ) at an elevation of $1315 \mathrm{~m}$ above mean sea level. Studies were established on an Alliance silt loam soil (fine-silty, mixed, superactive, mesic Aridic Argiustoll) in 1999-2000 and 2000-2001, and on a Duroc loam soil (fine-silty, mixed, superactive, mesic Pachic Haplustoll) in 2001-2002.

Five spring crop treatments (spring canola, oat + pea for forage, proso millet, dry bean, and corn) were no-till seeded into fields following sunflower in a randomized complete block design with five replications during 1999, 2000, and 2001. A chemical summer fallow treatment was included for comparison purposes. When needed, glyphosate [ $N$-(phosphonomethyl) glycine] was used to control weeds during the non-crop periods. Cultural practices are summarized in Table 1. Individual plots were 15.2 by $15.2 \mathrm{~m}$. Immediately before planting the first spring crop treatment, 10 soil samples were taken from the study area and composited in depth increments of $30 \mathrm{~cm}$ to a depth of $120 \mathrm{~cm}$ for gravimetric soil water content and in depth increments of 0 to 20,20 to 60 , and 60 to $120 \mathrm{~cm}$ for soil nutrient analysis. Spring crop treatments were fertilized according to University of Nebraska recommendations. Fertilizer $\mathrm{N}$ was supplied as liquid ammonium and/or ammonium nitrate. No P fertilizer was required.

Spring-planted crop yields were determined by harvesting a $1.2-$ to $1.8-\mathrm{m}$ by $15.2-\mathrm{m}$ strip through the middle of each plot. The remainder of the plot was then harvested and all straw was returned to the plot. A plot swather was used to cut and windrow canola, dry bean, and proso millet before harvest with a plot combine. Oat + pea for forage was swathed and harvested by hand. Corn was harvested with a plot combine. Grain or seed test weight and moisture content were determined with a grain analysis computer (DICKEY-John

Abbreviations: DI, disease index; DR, disease severity rating. 
Table 1. Summary of cultural practices for spring-planted crops and summer fallow.

\begin{tabular}{|c|c|c|c|c|c|c|}
\hline Crops & Cultivars & Seeding dates & Seeding rate & Row spacing & Herbicides applied $\dagger$ & Harvest dates \\
\hline & & & seeds $\mathbf{m}^{2}$ & $\mathbf{c m}$ & & \\
\hline \multirow[t]{3}{*}{ Spring canola } & Rider RR & 19 Apr. 1999 & 237 & 25.4 & glyphosate & 29 July 1999 \\
\hline & & 10 May 2000 & & & glyphosate & 27 July 2000 \\
\hline & & 3 Apr. 2001 & & & glyphosate & 17 Aug. 2001 \\
\hline \multirow{3}{*}{$\begin{array}{c}\text { Oat }+ \text { pea } \\
\text { forage }\end{array}$} & Russell/Arvika & 16 Mar. 1999 & 138/83 & 25 & none & 1 July 1999 \\
\hline & & 28 Mar. 2000 & & & none & 22 June 2000 \\
\hline & & 3 Apr. 2001 & & & none & 15 June 2001 \\
\hline \multirow[t]{3}{*}{ Corn } & Pioneer 3893 & 5 May 1999 & 4 & 76 & alachlor + atrazine & 30 Sep. 1999 \\
\hline & Asgrow DX 445RR & 9 May 2000 & & & atrazine and glyphosate & 14 Sep. 2000 \\
\hline & Asgrow DX 489RR & 10 May 2001 & & & glyphosate & 23 Sep. 2001 \\
\hline \multirow[t]{3}{*}{ Proso millet } & Sunrise & 24 Мау 1999 & 304 & 25 & 2,4-D amine + dicamba & 21 Aug. 1999 \\
\hline & Earlybird & 31 May 2000 & & & none & 5 Sep. 2000 \\
\hline & Sunrise & 15 June 2001 & & & none & 6 Sep. 2001 \\
\hline \multirow[t]{2}{*}{ Dry bean } & Harris & 3 June 1999 & 11 & 25 & dimethenamid + imazethapyr + bentazon & 7 Sep. 1999 \\
\hline & & 6 June 2000 & & & dimethenamid + imazethapyr & $\begin{array}{c}\text { none } \\
11 \text { Sep } 2001\end{array}$ \\
\hline Summer fallow & - & $\begin{array}{c}\text { I1 June } 2001 \\
-\end{array}$ & - & - & $\begin{array}{l}\text { S-metolachlor } \\
\text { glyphosate }\end{array}$ & $\begin{array}{c}11 \text { sep. } 2001 \\
-\end{array}$ \\
\hline
\end{tabular}

+ Chemical names: alachlor, 2-chloro- $N$-(2,6-diethylphenyl)- $N$-(methoxymethyl)acetamide; atrazine, 6-chloro- $N$-ethyl- $N$ '-(1-methylethyl)-1,3,5-triazine-2,4diamine; bentazon, 3-(1-methylethyl)-(1H)-2,1,3-benzothiadiazin-4(3H)-one 2,2 dioxide; 2,4-D, (2,4-dichlorophenoxy)acetic acid; dicamba, 3,6-dichloro2-methoxybenzoic acid; dimethenamid, 2-chloro- $N$-[(1-methyl-2-methoxy)ethyl]- $N$-(2,4-dimethyl-thien-3-yl)-acetamide; glyphosate, $N$-(phosphonomethyl)glycine; imazethapyr, 2-[4,5-dihydro-4-methyl-4-(1-methylethyl)-5-oxo- $H$-imidazol-2-yl]-5-ethyl-3-pyridinecarboxylic acid; s-metolachlor, 2-chloro- $N$ (2-ethyl-6-methylphenyl)- $N$-(2-methoxy-1-methylethyl)acetamide.

Corp., 231 W. Van Buren, Auburn, IL). Yields were adjusted to a constant moisture content. In the case of oat + pea for forage, wet weights were determined in the field with a tripod and scale. A representative subsample was taken, oven-dried at $43^{\circ} \mathrm{C}$ for $5 \mathrm{~d}$, and forage moisture content calculated. Forage yields are given on a dry weight basis. Dried forage subsamples were milled with a Wiley shear mill (A.H. Thomas, Philadelphia, PA) using a $0.5-\mathrm{cm}$-diameter round screen and stored at room temperature in plastic bags until crude protein was determined with a near-infrared reflectance sprectrophotometer (Technicon Infralyzer 500, Bran \& Luebbe Analyzing Technologies, Buffalo Grove, IL).

Immediately before seeding winter wheat, two soil samples per plot were taken and composited in depth increments of $30 \mathrm{~cm}$ to a depth of $120 \mathrm{~cm}$ for gravimetric soil water content and in depth increments of 0 to 20,20 to 60 , and 60 to $120 \mathrm{~cm}$ for soil nitrate $\mathrm{N}$ content. Five $\mathrm{N}$ fertilizer treatments $(0,22$, 45,67 , and $90 \mathrm{~kg} \mathrm{~N} \mathrm{ha}^{-1}$ ) were randomly assigned to each previous spring crop treatment. Nitrogen fertilizer was applied by hand as ammonium nitrate on 9 Mar. and 14 Nov. 2000, and 18 Oct. 2001.

Soil surface residue cover was determined for each spring crop treatment following winter wheat seeding by averaging the results of two line transect measures per plot. In June of each year, the distance within a row required to count 100 reproductive wheat tillers was measured and converted to reproductive tillers per square meter. Immediately before wheat harvest, $1 \mathrm{~m}$ of row from each subplot was clipped at ground level, bagged, and weighed. The sample was subsequently threshed and the grain cleaned and weighed. A harvest index was calculated.

In the early spring of 2000, 2001, and 2002, wheat plant samples were collected from $0.5 \mathrm{~m}$ of the center row in plots treated with 0 and $45 \mathrm{~kg} \mathrm{~N}^{-1}$, washed clean of adhering soil, and given a disease severity rating (DR) of 0 to 4 , with 4 being most severe. A disease index (DI) based on a 0-to-4 scale and previously used for other root diseases (Harveson and Rush, 1994; Harveson and Rush, 2002) was then calculated from the disease severity rating by the following equation: $\mathrm{DI}=(\mathrm{DR} 1+\mathrm{DR} 2 \times 2+\mathrm{DR} 3 \times 3+\mathrm{DR} 4 \times 4) /(\Sigma \mathrm{DR} 0-4)$.

Winter wheat grain yields were determined by combine harvesting a 1.8- by 9.1-m strip from the center of each fertilizer treatment plot. Grain test weight and moisture content were determined with a grain analysis computer (DICKEY-John
Corp., 231 W. Van Buren, Auburn, IL). Yields were adjusted to a constant moisture content of $125 \mathrm{~g} \mathrm{~kg}^{-1}$.

Gross returns were calculated based on 5-yr average prices for the region, excluding any government payments (Table 2). Cost of production budgets were developed for each springplanted crop using common production practices and the University of Nebraska budget generator. These values were used to determine the return to land and management for each observation with an annualized return developed for the 2-yr spring-planted crop-winter wheat system.

Data for the spring-planted crops were analyzed as a randomized complete block. Winter wheat data were analyzed as a split-plot experiment. The whole-plot treatment factor was previous spring crop arranged in randomized complete blocks. Nitrogen fertilizer level was the split-plot factor. Analysis of variance was performed using the general linear model procedure of SAS.

\section{RESULTS AND DISCUSSION}

Seasonal precipitation varied substantially from year to year during the course of this study (Table 3). April through August precipitation was 26 and $28 \%$ greater than the 30-yr mean in 1999 and 2001, but was 45\% below the 30-yr mean in 2000. Consequently, summer crop yields were generally greater in 1999 and 2001 than in 2000. Precipitation during the winter wheat growing season was 8 and $35 \%$ below the 30 -yr mean in 1999 2000 and 2001-2002, respectively, but was $20 \%$ greater

Table 2. Five-year average crop prices (1998-2002) for the Nebraska Panhandle and estimated crop production costs for 2002.

\begin{tabular}{lcc}
\hline Crop & Crop price & \multicolumn{2}{c}{ Cost of production $\dagger$} \\
\cline { 2 - 3 } Winter wheat & \multicolumn{2}{c}{$\$$ ha $^{-1}$} \\
Summer fallow & 0.11 & 142 \\
Oat + pea forage & - & 92 \\
Spring canola & 0.05 & 198 \\
Proso millet & 0.44 & 234 \\
Dry bean & 0.10 & 240 \\
Corn & 0.37 & 253 \\
\hline
\end{tabular}

$\uparrow$ Cost of production is an average of all observations for each crop. Actual cost will vary slightly based on crop yield. 
Table 3. Monthly precipitation totals for 1999 through 2002 compared to the 30-yr monthly mean precipitation at the High Plains Agricultural Laboratory near Sidney, NE.

\begin{tabular}{|c|c|c|c|c|c|}
\hline Month & 1999 & 2000 & 2001 & 2002 & 30-yr mean \\
\hline & & & $-\mathbf{n}$ & & \\
\hline January & 2 & 13 & 13 & 2 & 7 \\
\hline February & 3 & 9 & 13 & $\mathbf{1}$ & 8 \\
\hline March & 11 & 59 & 13 & 12 & 24 \\
\hline April & 101 & 54 & 85 & 8 & 38 \\
\hline May & 60 & 49 & 102 & 25 & 79 \\
\hline June & 85 & 29 & 38 & 30 & 78 \\
\hline July & 39 & 22 & 99 & 20 & 63 \\
\hline August & 97 & 14 & 66 & - & 46 \\
\hline September & 51 & 46 & 71 & - & 28 \\
\hline October & $\mathbf{0}$ & 37 & 24 & - & 20 \\
\hline November & 7 & 12 & 23 & - & 12 \\
\hline December & 6 & 1 & 0 & - & 7 \\
\hline Total & 460 & 347 & 548 & - & 411 \\
\hline
\end{tabular}

than the 30-yr mean in 2000-2001. During June, the critical grain-filling period for winter wheat, precipitation was 63,51 , and $62 \%$ below the 30 -yr mean in 2000 , 2001, and 2002, respectively.

\section{Winter Wheat Response to Preceding Crop}

Soil water at winter wheat planting was influenced by the preceding crop treatment (Table 4). Soil water content in the surface $1.2 \mathrm{~m}$ was always greatest after summer fallow, and with the exception of 2000, least after corn. In 2000, drought conditions resulted in early death for the corn crop, allowing late summer rains to be stored in the soil rather than be used by the crop. The 3-yr mean soil water content at winter wheat planting was 36 to $68 \%$ greater following summer fallow than following any other crop treatment. Additionally, soil water was more evenly distributed throughout the surface $1.2 \mathrm{~m}$ of soil after summer fallow than after other crop treatments, where the surface $0.3 \mathrm{~m}$ of soil was much wetter than at deeper depths (data not shown).

The amount of crop residue after winter wheat planting, measured as percent ground cover, was greatest after proso millet and corn, with the exception of the first winter wheat planting in 1999, when corn residue levels were not as great as proso millet residue levels (Table 5). The 3-yr mean ground cover levels after winter wheat planting were below $30 \%$ following summer fallow, dry bean, and spring canola. Although standing crop residue is not accurately measured by the line transect method, percent ground cover data in this study does reflect the trends in residue quantity, both flat and standing.

There was a significant year $\times$ crop $\times$ fertilizer inter-

Table 4. Gravimetric soil water content in the surface $1.2 \mathrm{~m}$ at winter wheat seeding following six spring crop treatments at Sidney, NE.

\begin{tabular}{lcccc}
\hline Preceding spring crop & 1999-2000 & 2000-2001 & 2001-2002 & 3-yr mean \\
\cline { 2 - 5 } & \multicolumn{5}{c}{ g kg $^{-1}$} \\
\cline { 2 - 5 } Summer fallow & 141 & 149 & 160 & 150 \\
Oat + pea forage & 102 & 102 & 124 & 110 \\
Spring canola & 91 & 92 & 121 & 102 \\
Proso millet & 91 & 85 & 122 & 99 \\
Dry bean & 94 & 104 & 115 & 104 \\
Corn & 72 & 94 & 102 & 89 \\
LSD (0.05) & 15 & 10 & 12 & 11 \\
\hline
\end{tabular}

Table 5. Percent ground cover after winter wheat planting following six spring crop treatments at Sidney, NE.

\begin{tabular}{|c|c|c|c|c|}
\hline Preceding spring crop & 1999-2000 & 2000-2001 & 2001-2002 & 3-yr mean \\
\hline Summer fallow & 12 & 18 & 17 & 16 \\
\hline Oat + pea forage & 37 & 42 & 21 & 33 \\
\hline Spring canola & 26 & 25 & 17 & 23 \\
\hline Proso millet & 65 & 51 & 43 & 53 \\
\hline Dry bean & 19 & 19 & 19 & 19 \\
\hline Corn & 30 & 48 & 43 & 40 \\
\hline LSD (0.05) & 9 & 7 & 4 & 4 \\
\hline
\end{tabular}

action $(p=0.012)$ for winter wheat grain yield. A significant yield response to fertilizer rate occurred following proso millet in $2000(p=0.008)$ and $2001(p=0.042)$, but there was no significant response to fertilizer rate following proso millet in $2002(p=0.852)$ or following any other crop treatment in any year. Consequently, wheat yield data were averaged across fertilizer rates to simplify the discussion of the response of wheat yield to the preceding crop.

Winter wheat yields were greater following summer fallow than following any of the spring crop treatments, with the exception of the 1999-2000 wheat crop when grain yield after oat + pea for forage was not significantly different from grain yield after summer fallow (Table 6). These findings agree with those of Nielsen et al. (2002) who found that the elimination of summer fallow before winter wheat planting reduced soil water at planting by $11.8 \mathrm{~cm}$ and wheat yields by 450 to 1650 $\mathrm{kg} \mathrm{ha}{ }^{-1}$, depending on growing season precipitation. The 3-yr average wheat yields and soil water at planting in our study fit their relationship well $\left(\mathrm{kg} \mathrm{ha}^{-1}=373.3+\right.$ $141.2 \times \mathrm{cm})$. Wheat yields were similarly reduced when legume crops were used to replace a portion of the summer fallow period before winter wheat planting in the Central Great Plains (Schlegel and Havlin, 1997; Vigil and Nielsen, 1998).

Using the 3-yr mean wheat grain yields, we ranked the preceding crop treatments as follows: summer fallow $>$ oat + pea for forage $>$ proso millet $>$ spring canola $=$ dry bean $>$ corn. The 3 -yr mean grain yield after summer fallow was $29 \%$ greater than following oat + pea for forage and $86 \%$ greater than following corn. Harvesting the oat + pea crop for forage allowed more time for additional soil water storage (Table 1). Grain protein content (3-yr mean $=138 \mathrm{~g} \mathrm{~kg}^{-1}$ ) was not affected by the preceding crop.

The 3-yr mean reproductive tiller densities were 485, $400,415,450,340$, and $370 \mathrm{~m}^{-2}$ for wheat following summer fallow, oat + pea for forage, proso millet, spring canola, dry bean, and corn, respectively. Wheat follow-

Table 6. Winter wheat grain yield following six previous crop treatments at Sidney, NE.

\begin{tabular}{lcccc}
\hline Preceding spring crop & 1999-2000 & 2000-2001 & 2001-2002 & 3-yr mean \\
\cline { 2 - 5 } & \multicolumn{4}{c}{ kg ha $^{-1}$} \\
\cline { 2 - 5 } Summer fallow & 2030 & 2930 & 1060 & 2010 \\
Oat + pea forage & 1790 & 2210 & 690 & 1560 \\
Spring canola & 1420 & 1420 & 590 & 1140 \\
Proso millet & 1590 & 2040 & 320 & 1320 \\
Dry bean & 1290 & 1190 & 520 & 1000 \\
Corn & 730 & 1540 & 250 & 840 \\
LSD (0.05) & 280 & 340 & 130 & 150 \\
\hline
\end{tabular}


Table 7. Winter wheat harvest index following six spring crop treatments at Sidney, NE.

\begin{tabular}{lcccc}
\hline Preceding spring crop & $\mathbf{1 9 9 9 - 2 0 0 0}$ & $\mathbf{2 0 0 0 - 2 0 0 1}$ & $\mathbf{2 0 0 1 - 2 0 0 2}$ & 3-yr mean \\
\cline { 2 - 5 } & \multicolumn{5}{c}{$\mathrm{g} \mathrm{kg}^{-1}$} & & \\
\cline { 2 - 5 } \cline { 3 - 5 } Summer fallow & 287 & 379 & $\mathbf{3 2 0}$ & $\mathbf{3 2 8}$ \\
Oat + pea forage & $\mathbf{3 0 7}$ & $\mathbf{3 9 4}$ & $\mathbf{3 5 4}$ & $\mathbf{3 5 2}$ \\
Spring canola & $\mathbf{2 9 8}$ & $\mathbf{3 3 3}$ & $\mathbf{3 3 8}$ & $\mathbf{3 2 3}$ \\
Proso millet & $\mathbf{3 4 1}$ & $\mathbf{3 4 5}$ & $\mathbf{3 0 5}$ & $\mathbf{3 3 0}$ \\
Dry bean & $\mathbf{3 0 6}$ & $\mathbf{3 5 2}$ & $\mathbf{3 6 5}$ & $\mathbf{3 4 1}$ \\
Corn & $\mathbf{2 1 8}$ & $\mathbf{2 9 2}$ & $\mathbf{3 1 4}$ & $\mathbf{2 7 4}$ \\
$\quad$ LSD (0.05) & $\mathbf{2 6}$ & $\mathbf{5 1}$ & $\mathbf{3 4}$ & $\mathbf{2 2}$ \\
\hline
\end{tabular}

ing corn, dry bean, and oat + pea for forage had significantly reduced tiller density compared with wheat after summer fallow $($ LSD $0.05=75)$. Plant stands following dry bean were poor. The surface soil after dry bean was hard enough at wheat planting that the drill was unable to plant at the desired depth. This resulted in reduced plant stands and subsequently reduced tiller densities. This hard soil surface condition may have been caused, in part, by the lack of crop residue remaining after dry bean harvest. This was not the situation following corn, where only proso millet had a greater quantity of residue after wheat planting (Table 5). Reduced tiller density after corn may have been the result of a later wheat planting date in 1999 and dry soil conditions in all years.

The effect of the preceding crop on the harvest index of wheat varied from year to year (Table 7). The 3-yr mean harvest index for wheat following oat + pea for forage was significantly greater than following summer fallow, while the harvest index for wheat following corn was significantly less than following summer fallow. The low harvest index values observed in this study were probably the result of late season (June) drought in all three years (Table 3 ), which limited grain yields relative to above-ground dry matter production. Dry conditions in June probably affected the harvest index of wheat following summer fallow the most, because its vegetative growth was least constrained by limited soil water (Table 4). The harvest index for wheat following oat + pea for forage may have benefited relative to wheat following summer fallow because drier soil conditions at planting after oat + pea for forage reduced vegetative growth compared to wheat following summer fallow. The low harvest index for wheat following corn was likely caused by poor grain yields resulting from insufficient water at planting.

An estimation of the quantity of wheat residue produced following each spring crop was calculated by dividing wheat grain yield by harvest index. The quantity of wheat residue was greatest following summer fallow in all three years (Table 8). Residue production following the spring crop treatments varied from year to year.

Table 8. Estimated winter wheat residue after wheat harvest following six spring crop treatments at Sidney, NE.

$\begin{array}{lllll}\text { Preceding spring crop } & 1999-2000 & 2000-2001 & 2001-2002 & 3-y r \\ \end{array}$

\begin{tabular}{lrlrr}
\hline & \multicolumn{4}{c}{$\mathbf{k g ~ h a}^{-1}$} \\
\cline { 2 - 5 } \cline { 3 - 5 } Summer fallow & $\mathbf{7 2 2 0}$ & $\mathbf{7 8 0 0}$ & $\mathbf{3 5 1 0}$ & $\mathbf{6 1 8 0}$ \\
Oat + pea forage & $\mathbf{5 8 6 0}$ & $\mathbf{5 8 1 0}$ & $\mathbf{1 9 5 0}$ & $\mathbf{4 5 4 0}$ \\
Spring canola & $\mathbf{4 9 9 0}$ & $\mathbf{4 3 8 0}$ & $\mathbf{1 7 4 0}$ & $\mathbf{3 7 1 0}$ \\
Proso millet & $\mathbf{4 7 9 0}$ & $\mathbf{6 1 5 0}$ & $\mathbf{1 0 5 0}$ & $\mathbf{4 0 0 0}$ \\
Dry bean & 4280 & $\mathbf{3 4 3 0}$ & $\mathbf{1 4 4 0}$ & $\mathbf{3 0 5 0}$ \\
Corn & $\mathbf{3 4 0 0}$ & $\mathbf{5 5 7 0}$ & $\mathbf{8 1 0}$ & $\mathbf{3 2 6 0}$ \\
$\quad$ LSD (0.05) & $\mathbf{1 2 2 0}$ & $\mathbf{1 2 8 0}$ & $\mathbf{5 4 0}$ & $\mathbf{5 9 0}$ \\
\hline
\end{tabular}

Dryland corn yield was maximized at a theoretical winter wheat mulch level of $4400 \mathrm{~kg} \mathrm{ha}^{-1}$ when averaged across three Nebraska locations (Wicks et al., 1994). Nebraska dryland corn and sorghum producers are told they need to have between 4500 and $6700 \mathrm{~kg} \mathrm{ha}^{-1}$ of wheat stubble for maximum yields (Wicks and Klocke, 1989). The only treatments having a 3 -yr mean residue quantity at harvest of at least $4500 \mathrm{~kg} \mathrm{ha}^{-1}$ were summer fallow and oat + pea for forage. Producing less than this minimum quantity of residue may have negative implications for crops that follow winter wheat in the rotation.

The disease indices calculated from the root disease severity ratings remained relatively consistent among the $3 \mathrm{yr}$ of the study. There were no significant year $x$ crop interactions $(p=0.07)$; therefore, results for the 3 yr were combined. The disease ratings taken from wheat plants following canola, oat + pea for forage, or corn $(1.25,1.24$, and 1.09 , respectively) were significantly less $(p<0.001)$ than those grown following dry bean, proso millet, or summer fallow $(1.76,1.70$, and 1.79 , respectively).

Root and crown rot (also known as common root rot) is primarily a stress disease caused by a complex of root pathogens, including Bipolaris sorokiniana (Sacc.) Shoemaker, and/or Fusarium spp. This disease is common in the dryland wheat growing areas of the Great Plains. It is not surprising that proso millet had one of the greater levels of disease, as this crop can also be a host for the pathogens involved with this disease. However, it was surprising to find a similar disease level in wheat following summer fallow, dry bean, or proso millet.

One of the advantages of summer fallow was to store soil water (Table 4), and perhaps this is partially responsible for the greater degree of root disease in the subsequent wheat crop. The pathogens generally prefer moist conditions, and more moisture was available for growth and development of both plants and pathogens. Although disease levels were consistently and significantly reduced following canola, oat + pea for forage, and corn, the relatively low disease ratings for all treatments suggests that root and crown rot did not play a major role in wheat performance in this study.

\section{Winter Wheat Response to Nitrogen Application}

A significant yield response to fertilizer rate occurred following proso millet in $2000(y=1180+22.8 x-$ $\left.0.207 x^{2}, r^{2}=0.436, n=25, p=0.002\right)$ and $2001(y=$ $\left.2020+8.56 x-0.134 x^{2}, r^{2}=0.373, n=25, p=0.006\right)$, but there was no significant response to fertilizer rate following proso millet in 2002 or following any other crop treatment in any year. The lack of a yield response to increased $\mathrm{N}$ application following crops other than proso millet was not anticipated.

There was no significant response of wheat grain protein to $\mathrm{N}$ fertilizer rate $(p=0.189)$. Protein concentration averaged across years and preceding crop treatments was $138 \mathrm{~g} \mathrm{~kg}^{-1}$. Goos et al. (1982) reported that grain protein levels of more than $120 \mathrm{~g} \mathrm{~kg}^{-1}$ indicate that $\mathrm{N}$ is non-limiting for winter wheat grown in the central High Plains. The lack of a significant grain pro- 
Table 9. Nitrate- $N$ concentrations in the surface $1.2 \mathrm{~m}$ of soil before winter wheat planting at Sidney, NE.

\begin{tabular}{|c|c|c|c|c|}
\hline Preceding spring crop & 1999 & 2000 & 2001 & 3-yr mean \\
\hline & \multicolumn{4}{|c|}{$-\mathbf{m g ~ k g} \mathbf{~ k g}^{-1}$} \\
\hline Summer fallow & 10.4 & 2.6 & 3.6 & 5.5 \\
\hline Oat + pea forage & 4.1 & 3.4 & 6.1 & 4.6 \\
\hline Spring canola & 4.2 & 4.4 & 4.0 & 4.2 \\
\hline Proso millet & 1.7 & 3.3 & 4.1 & 3.0 \\
\hline Dry bean & 3.9 & 1.1 & 6.2 & 3.8 \\
\hline Corn & 3.9 & 2.1 & 6.0 & 4.0 \\
\hline LSD (0.05) & 1.0 & $\mathbf{N S} \dagger$ & NS & 1.5 \\
\hline
\end{tabular}

$\dagger$ NS, nonsignificant.

tein response to $\mathrm{N}$ fertilization and high average grain protein concentrations, combined with low wheat yields throughout the course of the study (Table 6), suggests that something other than $\mathrm{N}$ was limiting yields. We presume water was the most yield limiting factor in this study.

Using soil nitrate-N levels before wheat planting (Table 9), the University of Nebraska fertilizer recommendations (Blumenthal and Sander, 2002) called for additional $\mathrm{N}$ application in all cases except following summer fallow in 1999. Recommended fertilizer $\mathrm{N}$ rates were 0,74 , and $66 \mathrm{~kg} \mathrm{~N}^{-1}$ for wheat following summer fallow in 1999, 2000, and 2001, respectively (assumptions: wheat price $\$ 0.10 \mathrm{~kg}^{-1}$ and $\mathrm{N}$ price $\left.\$ 0.55 \mathrm{~kg}^{-1}\right)$. These recommendations were developed primarily from data obtained from conventionally tilled winter wheatfallow systems.

The lack of response to $\mathrm{N}$ in our study is in contrast to several studies that have suggested that as cropping intensity increases from winter wheat-fallow, a greater amount of applied $\mathrm{N}$ will be needed to maintain crop yields (Halvorson and Reule, 1994; Kolberg et al., 1996; Halvorson et al., 1999). However, Nielsen and Halvorson (1991) found that increasing levels of $\mathrm{N}$ fertility can be detrimental to wheat yields in water-limited conditions. Periods of drought conditions were experienced in all three wheat-production seasons of this study, particularly during the flowering and grain fill periods, and this may have contributed to the lack of wheat response (yield, grain protein content, reproductive tiller density, and harvest index) to $\mathrm{N}$ application. The elimination of summer fallow, however, will probably increase the frequency of water-limited conditions for winter wheat, and this may increase the variability of wheat response to $\mathrm{N}$ fertility compared to cropping systems with summer fallow.

\section{Economic Returns}

Summer fallow is a fixed cost within a cropping system. Replacing summer fallow with a spring-planted transition crop requires the additional crop revenue be sufficient to mitigate the additional costs and reduced wheat revenue associated with the transition crop. The net return derived from the transition crop must exceed the reduction in net return from the subsequent wheat crop, due to reduced wheat yields, for the crop to be considered a viable option.

Annualized net returns for each spring crop plus the
Table 10. Annualized net return for the spring crop and subsequent winter wheat crop at Sidney, NE.

\begin{tabular}{|c|c|c|c|c|}
\hline Preceding spring crop & 1999-2000 & 2000-2001 & 2001-2002 & 3-yr mean $\pm \mathrm{SD}$ \\
\hline \multirow{3}{*}{$\begin{array}{l}\text { Summer fallow } \\
\text { Oat }+ \text { pea forage }\end{array}$} & & & $\$ \mathbf{h a}^{-1}$ & \\
\hline & -6.33 & 41.56 & $-\mathbf{5 7 . 8 8}$ & $-7.55 \pm 49.73$ \\
\hline & 91.05 & -22.43 & -56.03 & $4.20 \pm 77.07$ \\
\hline Spring canola & $-\mathbf{5 0 . 2 9}$ & -106.49 & -127.85 & $-94.88 \pm 40.66$ \\
\hline Proso millet & 6.21 & -25.45 & -1.50 & $-6.91 \pm 16.51$ \\
\hline Dry bean & 101.63 & -127.60 & -63.01 & $-29.66 \pm 118.20$ \\
\hline Corn & -34.15 & -115.56 & -93.78 & $-81.17 \pm 42.14$ \\
\hline LSD (0.05) & 16.90 & 13.56 & 14.19 & 8.58 \\
\hline
\end{tabular}

subsequent winter wheat crop were calculated (Table 10). The 3-yr average annualized net return for the oat + pea forage treatment exceeded the summer fallow treatment $\left(-\$ 7.55 \mathrm{ha}^{-1}\right)$ by $\$ 11.75 \mathrm{ha}^{-1}$. There was no significant difference between the 3-yr average annualized net return for the summer fallow or proso millet treatments. Both of these spring crops are served by regional markets that are critical to the success of any alternative crop introduced into a localized cropping system.

The remaining spring crop treatments, (dry bean, corn, and spring canola) had significantly reduced annualized net returns compared with summer fallow. The 3 -yr average annualized net return for the dry bean treatment was $\$ 22.11 \mathrm{ha}^{-1}$ less than the summer fallow treatment; however, the potential for dry bean in this system is demonstrated by the 1999-2000 results where the dry bean treatment had the greatest annualized net return at $\$ 101.63 \mathrm{ha}^{-1}$. The annualized net return for corn was $\$ 73.62 \mathrm{ha}^{-1}$ less than the summer fallow treatment. There are established marketing channels for corn and dry bean in the region that would assist with the integration of these crops into dryland cropping systems.

Spring canola was the lowest returning treatment with a reduction in annualized net return of $\$ 87.33 \mathrm{ha}^{-1}$ less than the summer fallow treatment. Spring canola cultivars are not currently well adapted to this region. Spring canola was initially planted in mid- to late March (a time considered to be optimum for cool season crops to avoid heat stress during anthesis). Warm temperatures in March resulted in rapid germination and growth, followed by subfreezing temperatures in April that killed seedling plants and necessitated replanting. Replanting caused anthesis to occur during the heat of July and subsequently resulted in poor yields. A local market for significant canola production, should adapted cultivars be produced, will require some development in the region.

\section{CONCLUSIONS}

Winter wheat yield was adversely affected by the elimination of summer fallow after a spring-planted transition crop and before wheat planting in the Central Great Plains. This agrees with the survey results of Wicks et al. (2003) who found winter wheat yields and wheat stem densities were greater and weed density was less when winter wheat was seeded following an 11- to 14-mo fallow period rather than a 0 - to 5-mo period. However, our results suggest that using a spring-planted forage crop with an early harvest date such as oat + pea, or a short duration spring-planted grain crop such as proso millet, to transition from a full-season summer crop to winter wheat may minimize the negative impact 
of eliminating summer fallow on the subsequent wheat crop. In fact, oat + pea for forage followed by winter wheat had a 3-yr average net return that was greater than summer fallow followed by winter wheat. A combination of returns to the spring-planted transition crop (fallow replacement crop) + relative wheat returns indicates that systems without summer fallow are feasible. System improvement may come from improving transition crop yields (e.g., better adapted spring canola) or decreasing the negative effects of the transition crop (e.g., dry bean) on wheat yields.

In this study, spring-planted crops were always planted after sunflower, one of the two most common full season summer crops in the Nebraska Panhandle. In Kansas, sunflower and grain sorghum removed more water than corn or soybean [Glycine max (L.) Merr.] at soil depths below $1.2 \mathrm{~m}$ (Norwood, 1999). Stone et al. (2002) found that water depletion following sunflower was greater than grain sorghum in the 2.2 to $3.3 \mathrm{~m}$ soil depth zone. Nielsen et al. (1999) noted reduced winter wheat and proso millet yields compared to winter wheat-fallow when these crops followed within $2 \mathrm{yr}$ of a sunflower crop. The fact that oat + pea for forage and proso millet were both economically competitive with summer fallow, even after sunflower, suggests that using a spring crop to transition from a full season summer crop to winter wheat may be more profitable if the summer crop uses less soil water than sunflower.

The results of this study have convinced us that alternatives to using summer fallow to transition from full season summer crops to winter wheat are possible in the semiarid Central Great Plains. Future research efforts will focus on identifying spring crops and management techniques that can best be used for this purpose. The elimination or significant reduction in the use of summer fallow in dryland cropping systems of the Central Great Plains will help protect the fragile soil resource from further degradation, improve water use efficiency, and increase the long-term viability of dryland farming in this region.

\section{ACKNOWLEDGMENTS}

The authors appreciated the technical assistance provided by Robert Higgins, Rex Nielsen, and Clay Carlson. The financial assistance provided by the University of Nebraska Foundation's Anna Elliott Fund is gratefully acknowledged.

\section{REFERENCES}

Blumenthal, J.M., and D.H. Sander. 2002. Fertilizing winter wheat. I. Nitrogen, potassium, and micronutrients. G02-1460-A. Univ. of Nebraska Coop. Ext., Lincoln, NE.

Daugovish, O., D.J. Lyon, and D.D. Baltensperger. 1999. Cropping systems to control winter annual grasses in winter wheat (Triticum aestivum). Weed Technol. 13:120-126.
Dhuyvetter, K.C., C.R. Thompson, C.A. Norwood, and A.D. Halvorson. 1996. Economics of dryland cropping systems in the Great Plains: A review. J. Prod. Agric. 9:216-222.

Farahani, H.J., G.A. Peterson, D.G. Westfall, L.A. Sherrod, and L.R. Ahuja. 1998. Soil water storage in dryland cropping systems: The significance of cropping intensification. Soil Sci. Soc. Am. J. 62: 984-991.

Goos, R.J., D.G. Westfall, A.E. Ludwick, and J.E. Goris. 1982. Grain protein content as an indicator of $\mathrm{N}$ sufficiency for winter wheat. Agron. J. 74:130-133.

Halvorson, A.D., A.L. Black, J.M. Krupinsky, and S.D. Merrill. 1999. Dryland winter wheat response to tillage and nitrogen within an annual cropping system. Agron. J. 91:702-707.

Halvorson, A.D., and C.A. Reule. 1994. Nitrogen fertilizer requirements in an annual dryland cropping system. Agron. J. 86:315-318.

Harveson, R.M., and C.M. Rush. 1994. Evaluation of fumigation and rhizomania-tolerant cultivars for control of a disease complex of sugar beets. Plant Dis. 78:1197-1202.

Harveson, R.M., and C.M. Rush. 2002. The influence of irrigation frequency and cultivar blends on the severity of multiple root diseases in sugar beets. Plant Dis. 86:901-908.

Kolberg, R.L., N.R. Kitchen, D.G. Westfall, and G.A. Peterson. 1996. Cropping intensity and nitrogen management impact of dryland no-till rotations in the semi-arid western Great Plains. J. Prod. Agric. 9:517-522.

McGee, E.A., G.A. Peterson, and D.G. Westfall. 1997. Water storage efficiency in no-till dryland cropping systems. J. Soil Water Conserv. 52:131-136.

Nielsen, D.C., R.L. Anderson, R.A. Bowman, R.M. Aiken, M.F. Vigil, and J.G. Benjamin. 1999. Winter wheat and proso millet yield reduction due to sunflower in rotation. J. Prod. Agric. 12:193-197.

Nielsen, D.C., and A.D. Halvorson. 1991. Nitrogen influence on water stress and yield of winter wheat. Agron. J. 83:1065-1070.

Nielsen, D.C., M.F. Vigil, R.L. Anderson, R.A. Bowman, J.G. Benjamin, and A.D. Halvorson. 2002. Cropping system influence on planting water content and yield of winter wheat. Agron. J. 94: 962-967.

Norwood, C.A. 1999. Water use and yield of dryland row crops as affected by tillage. Agron. J. 91:108-115.

Peterson, G.A., A.D. Halvorson, J.L. Havlin, O.R. Jones, D.J. Lyon, and D.L. Tanaka. 1998. Reduced tillage and increasing cropping intensity in the Great Plains conserves soil C. Soil Tillage Res. 47:207-218.

Peterson, G.A., A.J. Schlegel, D.L. Tanaka, and D.R. Jones. 1996. Precipitation use efficiency as affected by cropping and tillage systems. J. Prod. Agric. 9:180-186.

Schlegel, A.J., and J.L. Havlin. 1997. Green fallow for the Central Great Plains. Agron. J. 89:762-767.

Stone, L.R., D.E. Goodrum, A.J. Schlegel, M.N. Jaafar, and A.H. Khan. 2002. Water depletion depth of grain sorghum and sunflower in the Central High Plains. Agron. J. 94:936-943.

Smika, D.E. 1970. Summer fallow for dryland winter wheat in the semiarid Great Plains. Agron. J. 62:15-17.

Vigil, M.F., and D.C. Nielsen. 1998. Winter wheat yield depression from legume green fallow. Agron. J. 90:727-734.

Wicks, G.A., D.A. Crutchfield, and O.C. Burnside. 1994. Influence of wheat (Triticum aestivum) straw mulch and metolachlor on corn (Zea mays) growth and yield. Weed Sci. 42:141-147.

Wicks, G.A., and N.L. Klocke. 1989. Ecofarming: Spring row crop planting and weed control in winter wheat stubble. G81-551-A. Univ. Nebraska Coop. Ext., Lincoln, NE.

Wicks, G.A., D.H. Popken, G.W. Mahnken, G.E. Hanson, and D.J. Lyon. 2003. Survey of winter wheat (Triticum aestivum) stubble fields sprayed with herbicides in 1998: Cultural practices. Weed Technol. 17:467-474. 